\title{
What Drives Politicians to Run for Office: Money, Fame or Public Service?
}

\author{
Arpie G. Balian', Arman Gasparyan ${ }^{2}$
}

\begin{abstract}
This is a multiple case study that investigates the motivations and ambitions of politicians who run for elections. It uses a mixed research design that applies inductive reasoning in the collection and analysis of data from six communities of rural Armenia. Data-collection instruments include in-depth interviews, focus groups, field observations and community survey. Whereas the study considers various theories of motivation and ambition, the conclusive evidence shows that the attractiveness of office at the local-government level in smaller rural communities is not driven by financial considerations and is rather compelled by the desire to make a difference motivated primarily by personal interest in and dedication to bringing positive change in the quality of life in one's own community. The study also shows that motivators often stem from several other factors, including one's deep-rooted connection with the community, lineage, length of term in office, record of community satisfaction, resultant personal power built over the years in service and the need to be acclaimed by one's own community. A derivative closely linked to the priority of building the personal reputation of an incumbent mayor is the resultant power of decision-making. These conclusions can be explained using the model offered by Besley and Ghatak (2005) where politicians view public service as a personal mission. This study connects personal drive to sense of community and ancestral presence. The study also explains why mission accomplishment is more attractive than personal profit-making and how the sense of community and ownership are linked to personal drive.
\end{abstract}

1 Professor of Political Science and International Affairs, American University of Armenia, Yerevan, Armenia.

2 MA in Political Science and International Affairs, American University of Armenia, Yerevan, Armenia. 


\section{Key words:}

motivation; political ambition; personal drive; fame; recognition; public service; election; aspiration; term in office; community.

\section{Introduction}

Political scientists and public-sector analysts have long been interested in behaviors and patterns of motivation related to participation in elections. Whereas most studies focus on citizen participation, some have investigated the factors that motivate individuals to run for public office. The motivating factors are many and include authentic interest and the drive to enable positive change in the quality of life and upward mobility of society; one's keen interest in public service; ambitions related to personal ego; monetary incentives; need for recognition by the community; and others. No doubt, there is an overriding majority of those that run for office for the appeal of holding political power. Along those lines, Perry and Hondeghem (2008) argue in favor of both intrinsic and extrinsic motivators that often include security of tenure for the duration of the term of office; other scholars also consider future political career aspirations, financial security considerations and factors related to political trust and efficacy of political leaders (Cook and Gronke 2005; Hetherington 2005; Piven and Cloward 1997; Cohen and Dawson 1993).

Observations of public figures in post-Soviet republics often raise questions as to the reasons why they run for public office, especially for local government in rural villages. What triggers interest in running for office? Are the drivers that motivate candidates to run for local office similar? Do the motivating drivers to run for office also motivate incumbents to perform well and run again? Do the earlier drivers to run for office prevail in running a second or multiple times? Do those same reasons serve as catalysts for high performance? And, finally, is a candidate's personal vision for self-actualization related to the desire to make things better for the community?

In certain countries, incentives such as stable income and the prestige of being in office matter most in the decision to run for public office (Ferraz and Finan 2009). Some candidates run inspired by the general desire to contribute to their communities, while others are motivated by personal or public dissatisfaction with the incumbent and the belief that they could do a better job. Yet, there are others that run with the support of their respective parties or to maintain their party's lo$\mathrm{cal} /$ regional majority power.

\subsection{Theoretical Framework}

Studies on elections and political office have focused on identifying how voter preferences are determined and how local leaders/mayors implement authority, i.e. style of leadership and span of administrative controls. Researchers have paid little 
attention to examining what sparks interest in individuals to run for office in the first place. Schlesinger $(1966,6-9)$ argues that "the politician as office-seeker engages in political acts and makes decisions appropriate to gaining office." This and other studies in this realm do not delve into what generates the desire to run for office but are instead limited to examining the political process of gaining office and performance-related implications related to re-election and political advancement.

Further, research on performance in office links differences among office holders to their respective skills and abilities (Bardhan 2002), yet other studies link performance to local-government characteristics, including networking and entrepreneurial skills, electoral competition and voter participation (Besley and Burgess 2002; Grindle 2007). There are also limited attempts at investigating other factors that impact performance results, including history and geography (Golley 2002). But aside from those, it is inconceivable that in small rural communities established old ties within a community do not convert to determination to make a difference. Despite the vast focus on democratic processes related to local government, the literature has paid little attention to candidate motivations derived from deep-rooted community ties. To make sense of micro-level policy reform and citizen-centered political transactions, one ought to look into questions of motivation and linkages, if any, in the context of elections and performance in office.

This leads to the question as to where values, beliefs and incentives to run for office originate. Scholars in the predisposition paradigm typically posit that socialization is critical to influencing and shaping public opinion. Others explaining the material paradigm suggest that people's political behavior is influenced by their financial interests and relative position in the economy. Thus, aside from someone's current position in the income distribution, "the prospect of upward mobility" influences political decisions (Rehm 2009: 14). Considering the disparities among existing claims, together with differences in election behavior at the national and local levels of government, there is merit in examining the incentives that are dominant in rural communities.

The current study examines the situation in the Republic of Armenia, a 25-year-old independent republic established after the collapse of the Soviet Union. In the first section of the article, existing theories of motivation to run for office are reviewed briefly and, in subsequent sections, focus is placed on the collection, analysis and interpretation of data from six rural communities in Armenia.

\section{Theories of Motivation to Run for Office}

\subsection{Expectancy Theory}

Early studies in the field apply expectancy theory (Vroom 1964; Lawler et al. 1968), suggesting that candidates follow courses of action that would maximize the prob- 
ability of desirable outcomes for themselves. Along those lines, Isaac et al. (2001, 215 ) argue that candidates create various expectations in followers to influence their psychological processes or to "create expectations resulting from perceptions of their environments." In contrast to this line of thought, Black (1972) demonstrates the profound influence that the political system has on the type of individuals who run for office. The two variables operationalized are the size of the community and the degree of competition in local elections. The latter author's main finding is that "the system does not cause either ambition or success in a direct sense", but it helps to "determine indirectly the kind of men whom we will find in various types of offices" (Black 1972, 158).

\subsection{Ambition Theory}

Other scholars take a different approach tackling the drive to run for office using the more self-centered ambition theory, recognizing that the state often functions as a system that supports national values to restrain the self-interests of politicians. In fact, elections are there to "uphold those values, both by disciplining politicians and providing a means of finding those who are fit to serve", argues Besley (2004). This raises the question whether or not that really happens in most countries of the world. Or, more specifically, is that what happens in developing countries? Several scholars support the argument that politicians are mostly motivated by their ambitious desire to influence policy (Wittman 1977; Calvert 1985; Alesina 1988). In an earlier publication, Alesina and Spear $(1987,1)$ argue that candidates do not necessarily "view winning an election as their only goal, but also as a means of implementing the policies most preferred by their constituencies." Diverting from this position, Wittman $(1983,155)$ argues that another variable, namely a candidate's interest in policy reform, affects election outcomes.

\subsection{Other Theories of Motivation Considered}

More recently, Besley and Ghatak (2005) put forth a model where politicians act as "agents" working for a specific cause. Looking into public bureaucracies, these authors call attention onto the importance of mission accomplishment as opposed to profit-making. Their study focuses on the importance of locale and the specific environment where a candidate aims to serve.

Another important contribution by Callander (2008) uses game theory to explain the outcome of electoral competition between two groups. Answering the question of whether modern-day politicians pursue policy outcomes or seek the perks of office, the author posits that electoral competition favors office-motivated politicians while the electoral mechanism limits this advantage, helping policy-motivated candidates win a significant segment of voters. Arguing for the importance of pay, O'Riordan $(2013,6)$ addresses several other factors, such as prestige and social standing, which contribute to a politician's decision to run for office, while rec- 
ognizing the significance of pay, at the minimum, and security of tenure. O'Riordan argues that "public service motivation does matter, and among the intrinsic reasons that come into play when individuals choose where to work is highly significant."

None of these theories are conclusive, leaving space for continued scientific debate. Several scholars (Besley 2007; Persson and Tabellini 2000; Chambers 2007) tackle the issue of political motivation. In that regard, Besley (2007) looks into the interaction of incentives raising two important issues. Firstly, he argues that elected officials cannot or should not limit their interest to hold office to a narrow political objective that they would easily give up and/or fail to reach. Secondly, what is more important is that citizens learn about an incumbent through observations of his/her performance and make their voting decisions accordingly. This means that politically motivated candidates who pursue policy goals are more likely to be reelected. Similarly, Krasa and Polborn (2012) analyze a model where voters are supple with candidates' political platforms, which is a reason why some candidates choose policy positions to maximize their win prospect.

Similarly, Persson and Tabellini $(2000,10)$ compare two different types of motivations: opportunistic and partisan, i.e., those who "care about the well-being of particular groups in society" and those who "maximize a social welfare function with disproportionate weights." The former opportunistic politicians can further be classified into two different sub-types: "office-seekers" or those whose only desire is to win the elections for the sake of holding office and "rent-seekers", who are more interested in extracting tangible personal gains. Some go on to state that neither opportunism nor partisanship is a preferred assumption or strategy at all times. The argument here is that political motivation depends on the problem at hand and these two types are not mutually exclusive - i.e., candidates can be both opportunistic and partisan at the same time.

Besley (2005) demonstrates that ideal models do not exist in the actual political environment. He argues that different members of a political class have different motivations and depicts his argument in a model built upon three key factors (formal, public-service motivation and rents). His model is based on several relational constructs, among which the "attractiveness ratio A" is the key driver. This aims to determine the degree of attraction for politicians to run for office, where $A=($ Rents + Wages $) \div$ (Public Service Motivation + Wages). According to Besley $(2005,53)$ "when the attractiveness ratio A appears large to many people, the pool of bad politicians who would like to run for office will be larger." This is best explained in terms of maximizing the nominator in the ratio, and more specifically the rents.

This line of thinking is found in a study by Ferraz and Finan (2007), who examine the impact of higher wages in attracting better politicians and ensuring improved performance, concluding that higher salaries positively affect legislative performance, resulting in better public value. A similar conclusion is found in an earlier study by Messner and Polborn $(2004,9)$ who demonstrate "that bad candi- 
dates run more often than good candidates," and, in the case of unattractive offices or positions with lower wages, good candidates free-ride rather than seeking positions with higher wages.

There also are counter views to the above. Matozzi and Merlo (2007), for example, analyze the career paths of modern-day politicians, identifying two main strands: (a) politicians who work in the sector until retirement (career politicians); and (b) those who switch from the public to the private sector (entrepreneurial politicians). What is more important here is that, according to these authors, an increase in the salary of a politician would decrease the "average quality of individuals who become politicians, decrease turnover in office, and may either decrease or increase the average quality of career politicians" (Matozzi and Merlo 2007, 3). These findings are aligned with the earlier conclusions by Diermeier et al. (2005) on the relation between higher wages for positions in office and the value of such a seat.

There are also other schools of thought, of which one claims that increasing or decreasing wages does not directly influence political behavior or motivation. Besley $(2003,30)$ examines the case of U.S. Governors, who are confined to a two-term limit. His main argument is that "in thinking about what makes office holding valuable, wages may not be of first order importance." This suggests that the prospect to stay in office longer is related to the motivating factors.

\section{Research Design and Methodology}

This is a multiple case study that used a mixed method (both qualitative and quantitative approaches). Data was collected in January through May 2016. The datacollection instruments were devised to investigate the phenomenon of what motivates politicians to run for public office and whether or not the motivating factor influences performance, public satisfaction and re-election. As such, the study also explored differences among multiple cases in the same state. Using this approach the research question was tackled from different perspectives through the analysis of data derived from multiple sources. Thus, in-depth interviews were conducted with each of the incumbent mayors of the cases selected for the study $(n=6)$. Subsequently, focus groups were organized in the community centers of those villages - one focus group was held in each village, except for $\mathrm{C} 3$, where two focus groups were held; elected council members of the cases under investigation and other community leaders were invited to participate in the focus groups, most of whom (90\% response rate) attended (participant numbers per group are shown in Table 3). The third data source was the community survey administered in person in each of the six villages with respondents selected randomly (sample sizes of each survey shown in Table 4); considering that mail surveys are not yet used in rural Armenia, the surveyor approached every third residence inviting the oldest household member 
available to take the survey. Finally, limited field visits were made, mainly to confirm findings from earlier data analyses.

A transformative sequential design was used in this study, affording the collection of rich sets of qualitative data in the initial phase, devising subsequent datacollection instruments upon the former consequently confirming and/or validating the findings through triangulation. The interviews conducted in the first phase of data collection and analysis helped raise questions for more astute interrogation and probing in the next phase. Thus, the focus groups that followed in-depth interviews tried to capture the motives and other explanations that have influenced the respective mayor's decision to run for office as viewed by respective councilmen and community leaders. In turn, the direct observations contributed to better understanding the uniqueness of each community - from a narrower sense of community unity, family lineage and significance.

The qualitative approach also added depth by capturing each case in its natural setting. In the subsequent phase, the survey completed the earlier image of the constituency through a measurement of citizen interest in political participation and satisfaction with mayor's job performance. These elements were analyzed in terms of the importance of community linkages, the unique characteristics of each community and other factors associated with the phenomenon. In cases necessitating further clarification, former candidates and/or candidates considering running for elections were also interviewed. The community survey was aimed at validating the findings from the qualitative analysis and recording the general public view before confirming the emerging patterns.

\subsection{Selection of Cases}

Purposive sampling was used in selecting cases that were information-rich but which also included a variety of peculiarities different from one another, but representative of other rural municipalities across the republic. Notably, the sample of cases included first-term mayors (the low end of years in service, which is dominant in more than 20 percent of the municipalities in Armenia by 2015 statistics) and multi-term mayors (prevalent in the remaining 80 percent of municipalities across rural Armenia). One of the key benefits derived from this sampling technique was the opportunity it afforded to gather large amounts of data through the use of different techniques, thereby accumulating a better cross-section of information and as much insight as possible into the experiences in each of the cases.

The cases were selected from two provinces with the purpose of including locales that are similar to other rural communities throughout the country. Thus, the cases were drawn from a province in the West, the smallest province of the country and a larger province in the North. The selection of the villages also took into account their (a) representativeness in terms of population size (ranging from 375 to 4,500 ) which is closely representative of other rural communities across the 
country ${ }^{3}$ ); (b) local economy (ranging from agriculture, tourism and other small and medium-size businesses); (c) average level of education and income of the local population; (d) cultural assets and other related factors. Table 1 below provides descriptive statistics of the cases selected, shown by village (labelled C1 through C6).

\section{Table 1}

Descriptive Statistics of Selected Cases

\begin{tabular}{|l|c|c|c|c|c|c|}
\cline { 2 - 7 } \multicolumn{1}{c|}{} & C1 & C2 & C3 & C4 & C5 & C6 \\
\hline Population & 375 & 2,220 & 4,450 & 1,010 & 1,800 & 715 \\
\hline Distance from state capital $(\mathrm{km})$ & 115 & 145 & 68 & 70 & 149 & 83 \\
\hline Size $\left(\mathrm{km}^{2}\right)$ & 17 & 40 & 36 & 45 & 31 & 44 \\
\hline $\begin{array}{l}\text { Mayor's term in office } \\
\left(1^{\text {st }}, 2^{\text {nd }} \text { or multiple }\right)\end{array}$ & $1^{\text {st }}$ & $2^{\text {nd }}$ & $2^{\text {nd }}$ & Multiple & $1^{\text {st }}$ & Multiple \\
\hline
\end{tabular}

\subsection{Analytical Methodology}

The content analysis of text (transcripts of in-depth interviews and focus groups) employed values coding, using the categories and schemes outlined in 4.1 below. This allowed capturing the participants' values, attitudes and beliefs related to what their perspectives are of the mayor's position; values coding was deemed appropriate for explaining "cultural values, identity, intrapersonal and interpersonal participant experiences and actions" (Miles et al. 2013, 75).

Transcripts of interviews and focus groups were disaggregated and coded by the factors of motivation established earlier: security, recognition, dedication, selfactualization and personal satisfaction. The coding for discourse analysis of the transcripts took into account the frequency of use of related words and phrases (depicted in section 4.1) as well as the degree of emphasis of spoken words (analyzed using discourse markers, acoustic parameters of speech and body language following the rubrics shown in Appendix I). This allowed a depiction of dominant patterns and helped build the evidential chain across cases through thematic arguments and, subsequently, through data matrices that combined qualitative and quantitative scores.

\subsection{Structure and hypotheses}

In the first instance, the study tried to establish whether or not personal security, most importantly financial security, is the most dominant motivator of mayoral office seekers in rural communities.

$\mathbf{H}_{1}$ : The motivation to run for mayoral office is primarily driven by the financial security the position affords.

3 This assumption will hold until the RA Consolidation project is fully implemented, which will increase the size of communities throughout the country. 
The study also focused on the relative extent to which intrinsic and extrinsic factors motivate candidates to run for mayoral office.

$\mathbf{H}_{2}$ : Of all the motivating factors considered - security, recognition, dedication, self-actualization, and personal satisfaction - dedication to public service is the dominant motivator in elections of small close-knit communities.

Additionally, the hypotheses tested differences in motivation based on longevity in position, past performance, power of influence, prominence and party backing.

$\mathbf{H}_{3}$ : Multiple-term candidates are relatively less motivated to make a difference in their communities than are first- or second-term candidates.

$\mathbf{H}_{4}$ : High-performing incumbent mayors are more motivated to run for re-election than are multiple-term mayors.

$\mathbf{H}_{5}$ : High-performing mayors build prominence in the community and have a stronger power of influence on the village council.

Throughout the analysis of data, explanations were sought by identifying dominant themes and patterns among various data sources - data from mayors' interviews and focus groups. Differences in findings were further checked and validated or dismissed using data from the community survey and field observations. The next section presents those iterations in the order of analysis completed.

\section{Data Analysis and Findings}

\subsection{Themes, categories and coding scheme}

The questionnaire used for the interviews and focus groups involved the following indicators derived from the theories discussed earlier, taking into account both intrinsic and extrinsic factors related to candidates' decision to run for public office. Thus, for each of the indicators, our analysis was based on the coding scheme shown below.

a. Security - expressed through words or phrases such as security of office; job security; financial security; steady monthly salary; and political career security; political aspirations.

b. Recognition - expressed through words or phrases such as prestige of position; popularity; respect by community; gaining reputation as community leader; and recognition and reward by community; recognition by affiliated party.

c. Dedication - expressed through words or phrases such as drive to contribute to wellbeing of the community; drive to influence local governance (including policy and administration); drive to improve public trust; drive to become a change agent; and satisfaction with public services. 
d. Self-actualization - expressed through words or phrases such as personal ambition to influence higher politics; ambition to demonstrate personal qualifications; need to show own acumen; urge to apply knowledge, skills and abilities; and personal dissatisfaction with earlier mayor(s).

e. Personal satisfaction - expressed through words or phrases such as personal satisfaction with the job; satisfaction mostly derived from changes positively affecting the community. (Subsequently, this allowed assessing the relationship between the motivation to run for office and subsequent performance in office.)

\subsection{Analysis of in-depth interviews}

The analysis of data from in-depth interviews with mayors $(n=6)$ integrated thematic content analysis with the detection of matches, parallels and divergences among the cases. In addition to content analysis of interview transcripts, this analysis also used coding on a scale of 1 (one) to 10 (ten) to capture the intensity of the statement following the rubrics shown in Appendix I. For each of the themes security, recognition, dedication, self-actualization and personal satisfaction, the rubrics were established to minimize subjectivity in scoring discourse for succeeding comparison with survey results.

The mayors' interviews produced a pattern depicting that mayoral candidates of small rural communities are mostly driven by the personal ambition to make a difference in the quality of the live sof locals. In all six cases studied, the mayors are descendants of families with strong community bonds going back several generations. In one case, the mayor's father and grandfather had served as community leaders under the Soviet regime, and the mayor regarded his tenure as an unquestionable civic duty and allegiance to the community. Most interviewees (5/6) spoke of their community members as their relatives, friends, but more in terms of being "one big family; ... everyone has some close relation with the other" (Mayor of C5). The slight deviation from this dominant observation appears in the community with the largest population of the six cases studied (C3).

Thus, across all six cases, the most dominant theme was the drive for community service depicted as dedication. Under this theme, the motivation to run for office was shown to be mostly driven by the respective candidate's ambition to contribute to his community, to keep the "family tradition of public service" (Mayor of $\mathrm{C} 1$ ) as articulated by some, but more importantly, to "see my friends and family live better and improve their standards of living. Our village deserves my attention, and I have an obligation to make things better" (Mayor of C2). When converted to numerical values, scores of $9 / 10$ are obtained in three of the most populated villages, with the lowest score in this category being 6/10. [Additional anecdotal evidence shows that this theme is dominant in many smaller villages and close-knit communities throughout the republic where elected mayors are natives of their respective 
communities and the mayor's position has stayed in the hands of the same family for multiple generations.]

A dominant supporting element in this category was the desire to make improvements, thereby increasing public satisfaction with the local government. This was found to be dominant and consistently advocated by all mayors without exception, whether they were in their first term in office, second or multiple. As one mayor voiced it, "the most important function of mayors is to make things happen; to negotiate positive change with regional government; to drive change that people can see and feel in their daily lives" (Mayor of C2). The interviewees were conscious of community needs and intimately familiar with what would satisfy voters. Along those lines, a first-term mayor commented "the people believed in me and elected me to make a change. I have the duty and obligation to make that happen (Mayor of C1)."

In line with ambition theory, personal recognition was measured by three elements, including prestige of holding office, reputation as a recognized leader as well as acknowledgment and reward by one's party. Affiliation with political parties was assessed by the mayors as sensible when viewed from the standpoint of "getting the attention of the government, getting things done in general" (Mayor of C4). But, all interviewees ranked recognition by a political party as secondary or tertiary to recognition by one's own community. "I need to be able to walk tall in my community. And, that kind of recognition by one's own people is something you earn with your work," (Mayor of C2) explained a second-term mayor. On the element of prestige, multi-term mayors that had enjoyed the prestige of office for long did not cease to be ambitious to continue in public service. The data revealed that the older the incumbent mayor, the need for (more) recognition was even higher, with C3 and C5 scoring $7 / 10$ and $8 / 10$, respectively.

Under the security theme (security of office), an earlier expectancy theory largely supported by Schlesinger (1966) and others was observed among those mayors who have the highest record of time in office but still draw personal satisfaction from achieving positive change in the quality of life of the community and building public trust. "I have been mayor for so long, but can't imagine myself doing anything different. What keeps me going is the drive to do more, because with the changes in lifestyle, new needs emerge that I'd like to attend to. But, leaving all that aside, serving this community still is a challenge" (Mayor of C6), were the words of an older mayor, with C4 and C6 scoring 7/10 and 6/10, respectively. This relatively higher score in those mayors that have been serving for multiple terms can also be explained by their sense of job security at an older age (too late for changing careers), complemented by the strong desire to continue in a leadership role in their respective communities, as verbalized by their expressed desire to run for re-election.

4 This finding was subsequently confirmed by an average 96 percent of community leaders and council members participating in the focus groups held in each village, $n=110$ (See Table 3). 
None of the remuneration-driven motivation theories (Ferraz and Finan 2009; Matozzi and Merlo 2007; Besley 2006) were supported in this study. All six mayors had other sources of income and did not consider the mayor's salary to be a factor of motivation. Thus, in all six cases, the mayors unilaterally stated that financial security played no role in their decision to run for office. "In fact, I spend more in this job than the salary I receive, whether on the community, to help someone or to get something done that is not covered by the budget. Such out-of-pocket disbursements add up to more than the salary I get from this job" (Mayor of C1), elaborated one mayor. Subsequently, analysis of the focus groups with community leaders investigated the opportunity costs of attracting more and even better candidates to run in the elections (primarily using mayors' salaries as a point of reference). Considering that official salaries of mayors in Armenia range between $\$ 215$ and $\$ 575$ (comparable to the average salary of an administrative assistant in a reputable local organization) it is doubtful that this would serve as an important factor attracting more people to run for office motivated by that alone. In most cases, the observations showed that incumbent mayors are financially self-sufficient. Additionally, in the case of the mayors studied, the observations also showed that there are some perks associated with holding a mayoral office (varied and difficult to value in monetary terms), which, however, are not at levels significant for affecting or driving motivation.

Other motivation theories were also tested. In the first instance, there was no attribution to the desire for influencing higher politics, compared to the concerted energy devoted to contributing to one's own community. Further, the need to exhibit personal acumen and demonstrate ability to make things better, as established by Besley and Ghatak (2005), was confirmed by younger first-term mayors; however, none was driven by personal ambition for influencing higher politics.

Within other models that use factors of public-service motivation (O'Riordan 2013) where personal dissatisfaction with former administrations plays a role in the decision to run for office, place of work and public-service motivation are claimed to matter most. In the cases studied, the intrinsic value of serving one's own community was the strongest, a pattern that came through regardless of term in office. Thus, the argument of the attractiveness of office (Besley 2005) did not apply. The mayors included in this study were not rent seekers, but were more concerned with increasing the quality of life in their respective communities. Statements such as "my heart aches for this community ... and I feel responsible for doing something to improve the life of our villagers" were dominant, albeit in varying intensity (Mayor of $\mathrm{C} 1$ ).

In addition to the factors of motivation presented above, mayors' views were also sought on the extent to which they thought the public was satisfied with their performance in office and their individual motivation to run for re-election. The content analysis of interviews was also scored on a scale of 1 to 10 (where 1 indicates the lowest score and 10 the highest) for ease of comparison with the data 
sets obtained from other sources. The scoring scale follows the pre-established words/phrases and indicators shown in 4.1 above. Table 2 presents a summary of the factors of motivation articulated by the mayors interviewed, as labeled by the corresponding village $\mathrm{C} 1$ through $\mathrm{C} 6$ to ensure anonymity.

Table $2^{5}$

Summary of Mayors' Motivating Factors ${ }^{6}$

\begin{tabular}{|l|c|c|c|c|c|c|}
\cline { 2 - 7 } \multicolumn{1}{c|}{} & C1 & C2 & C3 & C4 & C5 & C6 \\
\hline Security & 4 & 3 & 6 & 7 & 5 & 6 \\
\hline Recognition & 3 & 5 & 7 & 2 & 8 & 4 \\
\hline Dedication & 8 & 9 & 9 & 6 & 9 & 7 \\
\hline Self-Actualization & 9 & 9 & 3 & 5 & 3 & 2 \\
\hline Personal satisfaction & 9 & 10 & 10 & 8 & 8 & 8 \\
\hline Public satisfaction & 8 & 9 & 8 & 9 & 9 & 9 \\
\hline Motivation to run for re-election & 8 & 8 & 8 & 7 & 8 & 7 \\
\hline
\end{tabular}

\subsection{Analysis of focus groups and tertiary observations}

Table 3 below depicts the data collected from focus groups with council members and other community leaders, $n=110$. Aside from a warm-up discussion at the beginning of each session, answers to specific questions were sought from each participant (see Appendix IV). Throughout the study, the mayor's intense drive to bring about positive change in the community was ranked the highest by participants in the focus groups. In five of the six cases studied, the councilmen and community leaders clearly supported their respective mayor's statements affirming that his primary motive to run for office was to realize positive change in the community.

Thus, responses by focus-group participants to the question on what motivated the mayor to run for office were unwavering and uniform across the communities studied. Seeking voter perspectives as to why the mayor ran for office sought independent views about the incumbent mayor (compared to the self-assessments by the mayors themselves). For the six cases studied, the responses by council members and community leaders were affirmations of the earlier findings on the mayors' motives of running for office. Thus, the motivation to make a difference in the community was the most dominant theme. The analysis of the data from focus groups showed that the mayors' claims were confirmed by 100 percent of participants in five communities and by 77 percent in the sixth community (See Table 3). In the case of C3, several focus-group participants pointed to other factors of motivation, such as financial and job security that may also have had some impact on the may-

5 A more detailed depiction of Table 3 can be found in Appendix I.

6 Scale is one to ten, coded according to the established words/phrases shown in 4.1. 
or's decision to run for office. In all other cases, the responses were emphatic, leaving no room for further inquiry.

The tertiary observations of the municipalities studied, including their internal work environment and the manner in which the mayor and his staff communicated were also indicative of the desire to bring about positive change and devotion to public service. The direct observations revealed scenarios where local residents came to see if the mayor(s) could help them out in different personal matters, and every effort was made to provide assistance in the form of referrals or direct assistance. ${ }^{7}$ Indifferent attitudes commonly witnessed in Western democracies, such as "this is not my job" or "there is nothing we can do to help you" were not observed here, further suggesting mayors' close connection with members of the community and steadfast commitment to improving people's wellbeing beyond the call of municipal duty.

Also, closely in line with ambition theory, mayors' performance in office was found to be directly linked to their personal and office goals, totally for mayors with less seniority and partially for mayors with more seniority, and confidence in their public service record. After election, first-term mayors showed more ambition upon gaining popularity through good reforms and excellence in performance.

Further, in response to subsequent questions related to electing "a more qualified candidate" if the position were financially more attractive, the respondents answered in the negative. In all six cases studied, there was overall unanimity with the high level of public satisfaction with the incumbent's performance in office. Based on the responses by participants in the focus groups, public satisfaction with the mayor's performance was near perfect, 100 percent in five communities and a high 90 percent in the sixth community (see Table 3 ). This supports the reasoning of ambition theory by Alesina and Spear (1987) and Besley (2004) that only candidates who are better fit win the elections and then push for implementing the policies most preferred by their constituencies. This increases public satisfaction, thereby increasing their chances to win another term in office (as allowed by law). Indeed, several of the mayors in our study were in office for more than their first term.

From the perspective of village leaders participating in the focus groups, the observations revealed satisfaction with the mayors' performance viewed from different standpoints. Predominantly, participants referred to factors such as concern for and consideration of public needs, enthusiasm and willingness in reforming public services, fairness in treating various segments of the community and attention to the underprivileged. The other important elements mentioned by community leaders were improvements in community life and quality of public services and assistance with finding employment (mostly by connecting people).

7 The researchers also witnessed outright out-of-pocket assistance in a couple of instances. 
Table 3

Village Council and Leadership on Mayor's Motives \& Performance (\%)

\begin{tabular}{|c|c|c|c|c|c|c|}
\hline & $\mathbf{C 1}$ & $\mathbf{C 2}$ & C3 & C4 & C5 & C6 \\
\hline$n=110$ & 15 & 16 & $33^{8}$ & 15 & 16 & 15 \\
\hline \multicolumn{7}{|c|}{ Why did the incumbent mayor run for office? } \\
\hline Financial and job security & - & - & 13 & - & - & - \\
\hline Recognition & - & - & 3 & - & - & - \\
\hline Dedication & 100 & 100 & 77 & 100 & 100 & 100 \\
\hline Self-Actualization & - & - & 4 & - & - & - \\
\hline Personal satisfaction & - & - & 3 & - & - & - \\
\hline \multicolumn{7}{|c|}{$\begin{array}{l}\text { How satisfied are you with the mayor's governance and care for the community } \\
\text { well-being? }\end{array}$} \\
\hline Public satisfaction & 100 & 100 & 90 & 100 & 100 & 100 \\
\hline \multicolumn{7}{|c|}{$\begin{array}{l}\text { Do you think better remuneration and rents would attract more qualified } \\
\text { candidates? }\end{array}$} \\
\hline More qualified candidate & 0 & 0 & 29 & 0 & 0 & 5 \\
\hline Improved performance by mayor & 0 & 14 & 39 & 9 & 0 & 15 \\
\hline \multicolumn{7}{|c|}{ If this mayor ran again in the next elections, would you elect him again? } \\
\hline Chances of re-election & 100 & 100 & 89 & 100 & 100 & 95 \\
\hline
\end{tabular}

In triangulation with the other findings presented earlier, field observations did not show a departure from the dominant patterns related to dedication to the community. The way of life, local interests and level of involvement by community members revealed the same picture as in most other places. Some people were active, and others were not. In some villages, there was a community center, which drew more people to get involved. Though, overall, the observations demonstrated that there is not much of a difference among the cases examined. Informal comparisons with a few other villages that were not included in the current study confirmed that where the local citizenry is unhappy with the leadership they indicate so through their votes. In most places observed, the feeling of satisfaction or dissatisfaction was shared by the majority of the community. Thus observing a near $100 \%$ level of satisfaction was relatively common in smaller communities, where family ties were stronger and resultant group opinion visibly unanimous. Except for $\mathrm{C} 3$, which is the largest community in this multiple case study, all the others are relatively much smaller and appear to be more close-knit and united in their positions on issues related to their community.

Looking at these findings through Besley's (2005) model of relational constructs of attractiveness of a position through wages and rents (in the numerator) v.

8 Two focus groups were conducted in this largest village, with 17 and 16 participants, respectively. 
public-service motivation and wages (in the denominator), one would expect that higher wages and rents would be more attractive to candidates with better qualifications. Conversely, the focus groups and direct observations used in the current study led to a different finding. In the opinion of those community leaders and council members (some of whom could be viewed as past or future candidates), additional wages and rents would not be considered to be so-called magnets that would attract more qualified candidates. The more important factors that were cited were (a) the level of devotion to the community; (b) the persistence to follow through and get things done; (c) the network of connections one has with higher regional and national government and decision makers; and (d) the level of knowledge and understanding of the community itself, which, according to the respondents, requires "a local to run for office who understands us and feels our pain." This makes the "public-service motivation" in the denominator more important than the increase of the numerator(s).

\subsection{Community Survey}

Tertiary observations used in the current study were conducted primarily to afford confirmation of findings from in-depth interviews and focus groups. The data of these tertiary observations was derived from a survey with a random sample of local residents in each of the communities studied. The survey results are shown in Table 4.

The public survey results depicted in Table 4 show that the respective mayor's principal motivation to run for office is derived from dedication to community service. Regardless of the size of the community or the term of office, $70-79 \%$ of survey respondents across the cases substantiated that.

The next most dominant pattern was the level of satisfaction with the mayors' performance and care for community across the cases examined (82-92\%). This finding was consistent with the position of survey respondents that better remuneration and rents would not attract better candidates, insinuating, in many ways, that interest to serve in the mayoral position does not stem from the salary it pays. This pattern is in line with what Matozzi and Merlo (2007) and Diermeier et al. (2005) claim on the relation of higher wages and the value of the position or office. Here again, it can be inferred that particularly in smaller close-knit communities, interest in the well-being of the community surpasses personal considerations, whether financial or career-driven.

In line with the level of public satisfaction with the mayor's performance in the cases examined, the respective chance of re-election is high (81-90\%). The incumbents' motivation to run for re-election showed slightly lower but affirmative indicators $(60-80 \%)$ the lowest being that of the mayor that was in office the longest (C6). In the latter's case, field observations showed that it was burnout and age that 
affected the mayor's re-election motivation, although his vision for new community projects continued to be evident. ${ }^{9}$

Table 4

Community Survey on Mayor's Motives \& Performance (\%)

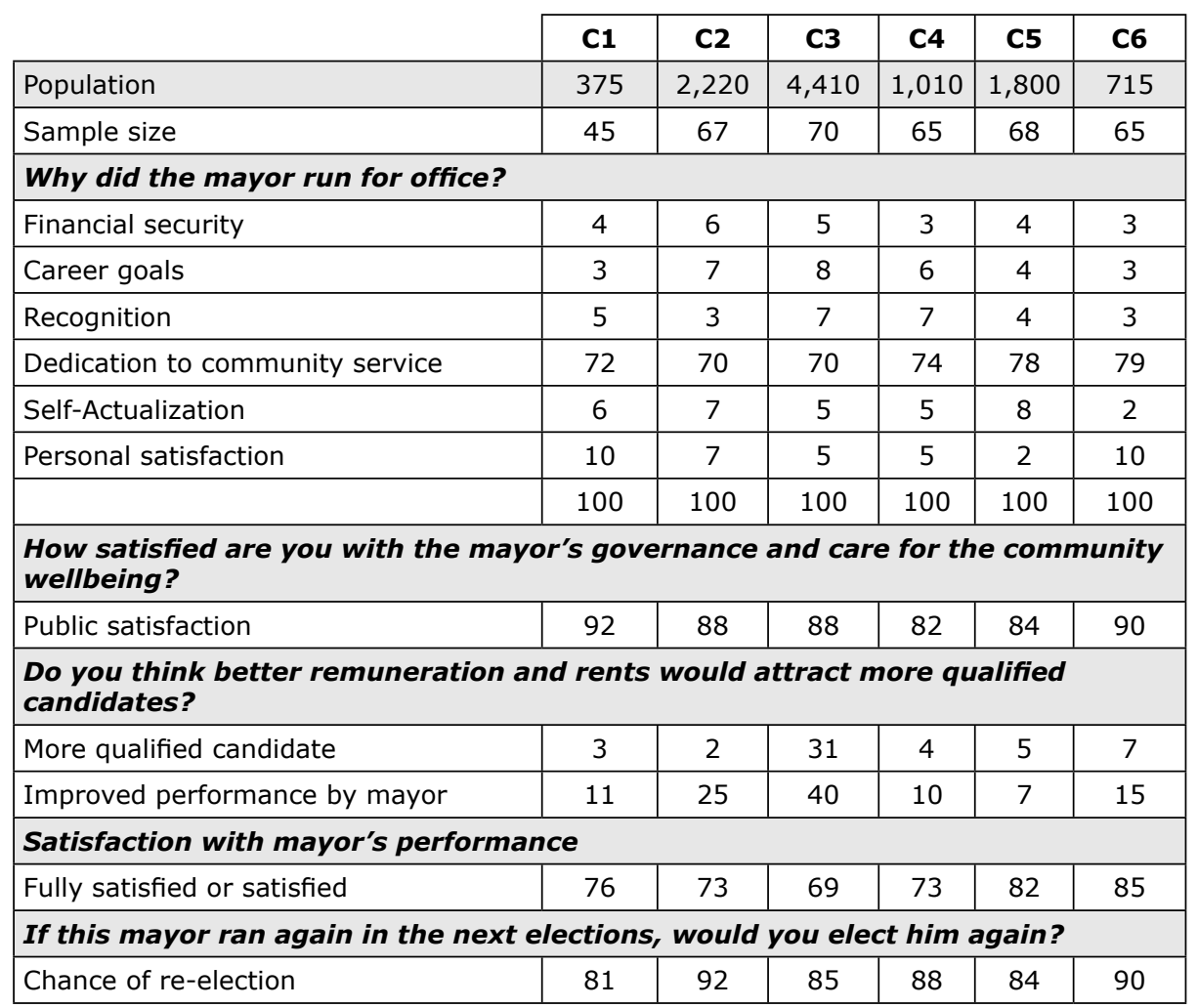

Statistically valid sample sizes at a confidence level of $90 \%$ and a confidence interval of $10 \%$.

\subsection{Combined Data and Conclusions}

In this study, cross-checks involved the deliberate combination of data from indepth interviews and focus groups in the qualitative section and the public survey from the quantitative approach (See Table 5). This was justified by the fact that mixed methods would more adequately answer the research questions or solve rival causal factors, if any. Data triangulation entailed the cross-checking of the consistency of specific and factual data collected from various sources using multiple methods (Patton 1990). Thus, data triangulation entailed the comparison of quali-

9 The mayor spoke about creating a new touristic attraction that would increase the visibility and historic significance of the village. 
tative data received from in-depth interviews with mayors and focus sessions with council members and community leaders with quantitative data from the survey of villagers.

Table 5 displays the mixed results in a matrix, which displays dominant themes in various sets of data, thereby generating the study results. In Table 5 the horizontal rows represent the villages studied. The columns represent the themes used throughout the stages. Within the columns, the summary of data is found in sub-columns reflecting each of the mayors' interviews (labeled $\mathrm{M}$ ), focus groups (labeled F) and community survey (labeled S). The scores shown earlier from the mayors' interviews and focus groups with councilmen and community leaders were converted to percentages to facilitate comparison with survey results. The emergent patterns discussed earlier show assertive consistencies among the data.

Table 5

Emerging Patterns from Combined Data Sources (\%)

\begin{tabular}{|c|c|c|c|c|c|c|c|c|c|c|c|c|c|c|c|c|c|c|}
\hline \multirow[b]{2}{*}{ C } & \multicolumn{3}{|c|}{ Security } & \multicolumn{3}{|c|}{$\begin{array}{l}\text { Recogni- } \\
\text { tion }\end{array}$} & \multicolumn{3}{|c|}{ Dedication } & \multicolumn{3}{|c|}{$\begin{array}{l}\text { Self-actu- } \\
\text { alization }\end{array}$} & \multicolumn{3}{|c|}{$\begin{array}{c}\text { Public } \\
\text { satisfaction }\end{array}$} & \multicolumn{3}{|c|}{ Re-election } \\
\hline & M & $\mathbf{F}$ & $\mathbf{S}$ & $\mathbf{M}$ & $\mathbf{F}$ & $\mathbf{s}$ & $\mathbf{M}$ & $\mathbf{F}$ & $\mathbf{S}$ & M & $\mathbf{F}$ & $\mathbf{s}$ & M & $\mathbf{F}$ & $\mathbf{S}$ & M & $\mathbf{F}$ & $\mathbf{S}$ \\
\hline 1 & 27 & - & 4 & 20 & - & 5 & 53 & 100 & 72 & 60 & - & 5 & 80 & 100 & 76 & 80 & 100 & 81 \\
\hline 2 & 20 & - & 6 & 33 & - & 3 & 60 & 100 & 70 & 60 & - & 7 & 90 & 100 & 73 & 80 & 100 & 92 \\
\hline 3 & 40 & 13 & 5 & 47 & 3 & 7 & 60 & 77 & 70 & 20 & 4 & 5 & 80 & 90 & 69 & 80 & 89 & 85 \\
\hline 4 & 47 & - & 3 & 13 & - & 7 & 40 & 100 & 74 & 33 & - & 5 & 90 & 100 & 73 & 70 & 100 & 88 \\
\hline 5 & 33 & - & 4 & 53 & - & 4 & 60 & 100 & 78 & 20 & - & 8 & 90 & 100 & 82 & 80 & 100 & 84 \\
\hline 6 & 40 & - & 3 & 27 & - & 3 & 47 & 100 & 79 & 13 & - & 2 & 90 & 100 & 85 & 60 & 95 & 90 \\
\hline
\end{tabular}

A hyphen (-) indicates a zero (0) value and $\mathrm{n} / \mathrm{a}$ indicates that the corresponding question was not asked.

In the table, $\mathrm{M}$ denotes mayors' interviews; $\mathrm{F}$ denotes focus groups; and $\mathrm{S}$ denotes survey. Village numbers are shown in the far left column labeled C.

The combined scores show evidence that among the examined factors of motivation dedication is strong across all data sources. Earlier, the first phase of the study tried to establish the dominant factors of motivation finding that financial security had the lowest influence on motivation across cases (although security of office has revealed slightly higher scores). The differences in scores among the cases examined were primarily driven by differences in the other two elements (security of office and security of future political career, the latter being within the neutral range). No significant differences were recorded between mayoral office seekers of smaller and larger villages.

There is sufficient consistent evidence to conclude that mayoral candidates' personal pursuit of financial security does not have a major effect on the decision to 
run for office. Even when the three elements of security are combined (see Table 5) the highest score of $53 \%$ appears in C5's motivation for recognition - a first-term mayor - which, however, is not voiced by others. There is self-acknowledgment that job security and recognition have played some role in his decision to run for office, albeit not dominant and not confirmed by others. Therefore, $H_{1}$ : The motivation to run for office is primarily driven by the financial security it affords - is refuted.

As shown in Table 5, the most dominant pattern emerging in the combined data is dedication. Among all factors tested, dedication stood out as a strong motivator from the interviews with mayors as well as focus groups and public survey; although slightly lower scores were recorded by multiple-term mayors themselves, these were not confirmed by the focus groups or the public. These minor variances are attributed to reflective consciousness of past failures or simply humility. Thus $\mathrm{H}_{2}$ : Of all the motivating factors considered - security, recognition, dedication, self-actualization, and personal satisfaction - dedication to community is the most dominant motivator in local rural elections - is accepted. Similarly, $\mathrm{H}_{3}: \mathbf{m u l}$ tiple-term candidates are less motivated to make a difference in their communities than first- or second-term candidates - is refuted. It is important to note here that multiple-term mayors who have accomplished a great deal and are aging may not have the same drive to run for office as before. As was explained by focus-group participants, what a mayor fails to accomplish stems not from his incompetence, but from constraints beyond the control of the municipal office or community. Regional and central governments often create barriers related to party affiliation, and the bulk of assistance or so-called "favors" go to ruling-party-affiliated mayors and communities.

In line with personal and public satisfaction, measured by two separate instruments often used as indicators of satisfaction with accomplishments, the desire to run again or incumbents' chances for re-election appear to be high across cases, but also interrelated. As motivation theories allude to, achievement behavior is derived from an individual's motivation to succeed. Speaking about implicit motives, Brunstein and Maier (2005) posit that those are expressed in performance and are aroused through incentives inherent to the task. Similarly, Rabideau (2005) claims that both intrinsic and extrinsic motivation can be derived from realized achievements and the expectation of rewards. This is a stronger feeling in first- and second-term mayors than in multiple-term mayors who are more established in their respective communities. Although the motive to run for re-election is the same across four villages ( $80 \%)$, multiple-term mayors have scored slightly lower $(70 \%$ and $60 \%$ ). Although the variance is slim $\boldsymbol{H}_{4}$ : Well-performing incumbent mayors are more motivated to run for re-election than multiple-term mayors - is accepted.

And finally, patterns were examined related to performance and power of influence, as measured by the council members' assessment of the incumbent mayors, respectively. As shown above, the highest scores throughout appear in focus groups; 
near perfect scores are dominant in the council members' views that the mayor's motivation stems from his dedication to community service; the degree to which the public is satisfied with the mayor's performance; and the incumbent mayor's reelection chances. The scores are slightly lower in the case of C3, the largest community in this study and only a second-term mayor. Direct observations and informal conversations with residents revealed that this community has had disagreements and problems with the previous mayor and is very cautious not to approve of the incumbent that quickly, although his re-election chances were pretty high $(89 \%$ and $85 \%$ by the focus group and public survey, respectively). We consider re-election to be the ultimate "power of influence". Therefore, $\mathrm{H}_{5}$ : High-performing mayors have built prominence in the community and have stronger power of influence on the village council - is accepted.

Unlike in national and big-city elections, party membership did not have a major effect on the initial motivation to run for office, but by what was conveyed in focus sessions party affiliation did help get projects through for funding and other related achievements that are highly connected to networks and affiliations.

\section{Conclusion}

The use of multiple data sources in this study has allowed consideration of the issue from intrinsic and extrinsic facets of the phenomenon, as well as understanding the differences among the cases, identifying the key drivers of motivation and underlying reasons. The research design employed in this study also afforded investigation of the research questions and related issues, particularly as they involved the decision to run for office. The themes established at the outset for measuring motivation took into account various political, social, personal and community considerations derived from related literature.

This multiple case study has shown that the attractiveness of an office at the local-government level from a purely financial perspective does not play a role in motivating candidates to run for office. In fact, considering the low wages and demonstrated manifestation of scanty rents, it would be difficult to get someone interested in the job except for the obligation to serve one's own community and aspiration to make a difference. Concerning the latter the reasons are many, including the authentic interest and drive to enable positive change in the quality of life and upward mobility of the community itself, affirming Wittman's (1983) theory. The value-added here is that the drive to serve one's own is primarily derived from longstanding close ties with the community.

The study also showed that other motivators stem from one's keen interest in public service in general (preferably in one's own community). Such interests stem from personal ego and the need to be acclaimed by one's own community, thereby making a name. Somewhat different from national election motivations, 
the decision to run for office was not directly linked to party affiliation, at least not dominantly, i.e. one out of the five cases studied may have shown such a penchant. A derivative closely linked to personal fame is the resulting power of decision making. In the case of multi-term mayors, there was a clear pattern of strong influence on council members, which increased the mayor's self-confidence and gained increased support for his policy agenda by the council. This can be explained using the model by Besley and Ghatak (2005), where politicians view public office as their mission (thus mission accomplishment is more attractive than personal profit).

It is therefore justified to predict that local rural elections in small and closeknit communities elsewhere in the world would also be driven by deep family ties and a strong sense of belonging. Here, caution must be exercised that this pertains to smaller villages, where community unity is high and where mayors are multigeneration natives of the village. This pattern is distinctly different from national elections that tend to be more competitive and party-driven. The findings also suggest looking into changes that may occur after the villages throughout Armenia are consolidated into larger communities when the motivation to run for office is expected to be more party-driven (which will be the next phase of the study after consolidation). The earlier study by Black (1972) had demonstrated the influence of the political system on the type of individuals who run for office. The two variables operationalized were the size of the community and the degree of competition in local elections. The findings from this research have shown that ancestral ties rather than the political system cause both ambition and performance success when eliciting the kinds of candidates to run for office.

\section{References}

Alesina, Alberto. 1988. "Credibility and Policy Convergence in a Two-Party System with Rational Voters." American Economic Review 78, 796-805.

Alesina, Alberto and S. E. Spear. 1987. "An Overlapping Generations Model of Electoral Competition." NBER Working Paper Series \#2354. Cambridge, MA: National Bureau of Economic Research.

Aragones, Enriqueta and Thomas Palfrey. 2002. "Mixed Equilibrium in a Downsian Model with a Favored Candidate." Journal of Economic Theory 103, 131-161.

Bardham, Pranab, 2002. "Decentralization of Governance and Development." Journal of Economic Perspectives 16(4), 185-205.

Besley, Timothy and Robin Burgess, 2002. "The Political Economy of Government Responsiveness: Theory and Evidence from India." The Quarterly Journal of Economics 117 (4), 1415-1451. 
Besley, Timothy. 2003. "Paying Politicians: Theory and Evidence." Joseph Schumpeter Lecture at the $18^{\text {th }}$ Congress of the European Economic Association in Stockholm.

Besley, Timothy. 2004. "Paying Politicians: Theory and Evidence." Journal of the European Economic Association 2, 193-215.

Besley, Timothy. 2005. "Political Selection." The Journal of Economic Perspectives 19, $43-60$.

Besley, Timothy. 2006. "Principled Agents? The Political Economy of Good Government." The Lindahl Lectures. Oxford, UK: Oxford University Press.

Besley, Timothy. 2007. "The New Political Economy." The Economic Journal 117(524), 570-587.

Besley, Timothy and Maitreesh Ghatak. 2005. "Competition and Incentives with Motivated Agents." American Economic Review 95, 616-636.

Black, G. S. 1972. "A Theory of Political Ambition: Career Choices and the Role of Structural Incentives." American Political Science Review 66, 144-159.

Brunstein, J. C. and G. W. Maier. 2005. "Implicit and Self-Attributed Motives to Achieve: Two Separate but Interacting Needs." Journal of Personality and Social Psychology 89, 205-222.

Callander, S. 2008. "Political Motivations." The Review of Economic Studies 75, 671-697.

Calvert, Randall L. 1985. "Robustness of the Multidimensional Voting Model: Candidate Motivations, Uncertainty, and Convergence." American Journal of Political Science 29, 69-95.

Chambers, C. 2007. "Citizen-Candidates, Lobbies, and Strategic Campaigning." Economic Theory 33, 285-309.

Cohen, Cathy J. and Michael C. Dawson. 1993. "Neighborhood Poverty and African American Politics." American Political Science Review 87, 286-302.

Cook, Timothy E. and Paul Gronke. 2005. "The Skeptical American: Revisiting the Meanings of Trust in Government and Confidence in Institutions." Journal of Politics 67(3), 784-803.

Diermeier, Daniel, Michael Keane and Antonio Merlo. 2005. "A Political Economy Model of Congressional Careers.” American Economic Review 95, 347-373.

Ferraz, Claudio and Frederico Finan. 2007. "Electoral Accountability and Corruption in Local Governments: Evidence from Audit Reports.” \#2843 IZA Working Papers. 
Ferraz, Claudio and Frederico Finan. 2009. Motivating Politicians: The Impacts of Monetary Incentives on Quality and Performance. Cambridge, MA: National Bureau of Economic Research Paper \#14906.

Florina, Morris. 1973. "Electoral Margins, Constituency Influence, and Policy Moderation: A Critical Assessment." American Political Quarterly 1, 479-498.

Fox, Richard L. and Jennifer L. Lawless. 2011. "Gaining and Losing Interest in Running for Public Office: The Concept of Dynamic Political Ambition." The Journal of Politics 73, 443-462.

Golley, Jane, 2002. "Regional Patterns of Industrial Development During Economic Transition." Economics of Transition, 10(3): 761-801.

Grindle, Merilee S. 2007. “Good enough governance." Development Policy Review 25(5). 533-574.

Hetherington, Mark, 2005. "Why Trust Matters: Declining Political Trust and the Demise of American Liberalism." Journal of Politics 54, 553-564.

Isaac, R. G., W. J. Zerbe and D.C. Pitt. 2001. "Leadership and Motivation: The Effective Application of Expectancy Theory." Journal of Managerial Issues 13(2), 212-226.

Krasa, S. and M. K. Polborn. 2012. "Political Competition between Differentiated Candidates." Games and Economic Behavior 76, 249-271.

Lawler, E. E., L. W. Porter and A. Tennenbaum. 1968. “Managers' Attitudes toward Interaction Episodes." Journal of Applied Psychology 52, 432-439.

Matozzi, Andrea and Antonio Merlo. 2007. "Political Careers or Career Politicians?” PIER Working Paper 007-009.

Messner, Matthias and Mattias Polborn. 2004. "Paying Politicians." Journal of Public Economics 88, 2423-2445.

Miles, Matthew B., A. Michael Huberman and Johnny Saldana. 2013. Qualitative Data Analysis. 3rd ${ }^{\mathrm{d}}$ ed. Thousand Oaks, CA: Sage Publications.

O'Riordan, Joanna. 2013. Public Service Motivation. State of the Public Service Series, Ireland: Institute of Public Administration.

Patton, M. 1990. Qualitative Evaluation and Research Methods, pp. 169-186. Beverly Hills, CA: Sage Publications.

Perry, James L., Annie Hondeghem, 2008. "Building Theory and Empirical Evidence about Public Service Motiation.” International Public Management Journal, 11(1), 3-12.

Persson, Torsten and Guido Tabellini. 2000. Political Economics: Explaining Economic Policy. Cambridge, Massachusetts: MIT Press. 
Piven, Frances Fox and Richard Cloward. 1997. The Breaking of the American Social Compact. New York: New York Press.

Rabideau, S. T. 2005. Effects of Achievement Motivation on Behavior. http://www. personalityresearch.org/papers/rabideau.html [accessed January 2015].

Rehm P., 2009. "Risks and Redistribution: An Individual-Level Analysis." Comparative Political Studies 42, 855-881.

Schlesinger, Joseph A. 1966. Ambition and Political Careers in the United States. Chicago: Rand McNally.

Vroom, V. 1964. Work and Motivation. New York, NY: Wiley.

Wittman, D. A. 1977. "Candidates with Policy Preferences: A Dynamic Model." Journal of Economic Theory 14, 180-189.

Wittman, Donald 1983. "Candidate Motivation: A Synthesis of Alternative Theories." American Political Science Review 77, 142-157. 


\section{Appendices}

\section{Appendix I - Rubrics for Discourse Analysis}

\begin{tabular}{|c|c|c|c|}
\hline & $\begin{array}{l}\text { Discourse Markers } \\
\text { (Weight } 40 \% \text { ) }\end{array}$ & $\begin{array}{c}\text { Acoustic Parameters of } \\
\text { Speech } \\
\text { (Weight } 30 \%)\end{array}$ & $\begin{array}{l}\text { Body Language } \\
\text { (Weight } 30 \% \text { ) }\end{array}$ \\
\hline 1 & $\begin{array}{l}\text { No sequencing }{ }^{10} \text {; no examples; } \\
\text { no reference to cause-and-effect; } \\
\text { no use of emphasis; absence of } \\
\text { dominant notion. }\end{array}$ & $\begin{array}{l}\text { No energy; hesitant pace } \\
\text { of communication; very low } \\
\text { voice pitch. }\end{array}$ & $\begin{array}{l}\text { No eye contact; } \\
\text { sloppy posture; } \\
\text { constant uneasiness. }\end{array}$ \\
\hline 2 & $\begin{array}{l}\text { No sequencing; no examples; } \\
\text { fake cause-and-effect; no use of } \\
\text { emphasis; depressed frequency of } \\
\text { dominant notion. }\end{array}$ & $\begin{array}{l}\text { Insignificant frequency } \\
\text { energy; unsure pace of } \\
\text { communication; very low } \\
\text { voice pitch. }\end{array}$ & $\begin{array}{l}\text { Evasive or no eye } \\
\text { contact; frequent } \\
\text { blinking; sloppy } \\
\text { physical posture; } \\
\text { constant fidgeting. }\end{array}$ \\
\hline 3 & $\begin{array}{l}\text { Minimal sequencing; one example; } \\
\text { fabricated cause-and-effect; no } \\
\text { use of emphasis; minimal use of } \\
\text { dominant notion. }\end{array}$ & $\begin{array}{l}\text { Insignificant frequency } \\
\text { energy; somewhat unsure } \\
\text { communication pace; voice } \\
\text { pitch too low and also } \\
\text { indicating vagueness. } \\
\end{array}$ & $\begin{array}{l}\text { Limited eye contact; } \\
\text { frequent blinking; } \\
\text { almost straight } \\
\text { posture; recurrent } \\
\text { nervous fidgeting. } \\
\end{array}$ \\
\hline 4 & $\begin{array}{l}\text { Some sequencing; rare examples; } \\
\text { shallow cause-and-effect; rare } \\
\text { use of emphasis; low frequency of } \\
\text { dominant notion. }\end{array}$ & $\begin{array}{l}\text { Almost insignificant } \\
\text { frequency energy; unsure } \\
\text { communication pace; } \\
\text { voice pitch not too low but } \\
\text { indicating vagueness. }\end{array}$ & $\begin{array}{l}\text { Some eye contact } \\
\text { but not steady; } \\
\text { sporadic blinking; } \\
\text { mostly good } \\
\text { posture; intermittent } \\
\text { fidgeting. }\end{array}$ \\
\hline 5 & $\begin{array}{l}\text { Casual sequencing; few examples; } \\
\text { weak cause-and-effect relationship; } \\
\text { rare use of emphasis; repeated } \\
\text { mention of one dominant notion. }\end{array}$ & $\begin{array}{l}\text { Normal frequency energy; } \\
\text { slow but sure communication } \\
\text { pace; voice pitch near normal } \\
\text { but not signaling confidence. } \\
\end{array}$ & $\begin{array}{l}\text { Regular eye contact; } \\
\text { some blinking; } \\
\text { normal posture; } \\
\text { minimal fidgeting. } \\
\end{array}$ \\
\hline 6 & $\begin{array}{l}\text { Random sequencing; common } \\
\text { examples; weak cause-and-effect; } \\
\text { occasional use of emphasis; subtle } \\
\text { frequency of dominant notions. }\end{array}$ & $\begin{array}{l}\text { Normal frequency energy; } \\
\text { normal communication pace; } \\
\text { voice pitch normal but not } \\
\text { signaling confidence. }\end{array}$ & $\begin{array}{l}\text { Regular eye contact; } \\
\text { occasional blinking; } \\
\text { normal posture; } \\
\text { almost no fidgeting. }\end{array}$ \\
\hline 7 & $\begin{array}{l}\text { Good sequencing; some good } \\
\text { illustrations; references to some } \\
\text { cause-and-effect; some use of } \\
\text { emphasis; normal frequency of } \\
\text { dominant notions. }\end{array}$ & $\begin{array}{l}\text { Good frequency energy; clear } \\
\text { articulation. }\end{array}$ & $\begin{array}{l}\text { Good eye contact; } \\
\text { almost no blinking; } \\
\text { good posture; no } \\
\text { fidgeting. }\end{array}$ \\
\hline 8 & $\begin{array}{l}\text { Strong sequencing; recurrent } \\
\text { illustrations; sound cause-and-effect; } \\
\text { normal use of emphasis; fairly high } \\
\text { frequency of dominant notions. } \\
\end{array}$ & $\begin{array}{l}\text { Good frequency energy; fine } \\
\text { articulation. }\end{array}$ & $\begin{array}{l}\text { Stable eye contact; } \\
\text { no blinking; } \\
\text { good posture; no } \\
\text { fidgeting. }\end{array}$ \\
\hline 9 & $\begin{array}{l}\text { Resolute sequencing; use of relevant } \\
\text { and significant illustrations; strong } \\
\text { cause-and-effect; frequent use } \\
\text { of emphasis; high frequency of } \\
\text { dominant notions. }\end{array}$ & $\begin{array}{l}\text { High frequency energy; } \\
\text { vibrant articulation. }\end{array}$ & $\begin{array}{l}\text { Reassuring eye } \\
\text { contact; no blinking; } \\
\text { strong posture; no } \\
\text { fidgeting. }\end{array}$ \\
\hline 10 & $\begin{array}{l}\text { Resolute sequencing; use } \\
\text { of relevant and significant } \\
\text { illustrations; great examples of } \\
\text { cause-and-effect; good use of } \\
\text { emphasis; repeated frequency of } \\
\text { dominant notions. }\end{array}$ & $\begin{array}{l}\text { High frequency energy; } \\
\text { very vibrant articulation. }\end{array}$ & $\begin{array}{l}\text { Reassuring eye } \\
\text { contact; no } \\
\text { blinking; strong } \\
\text { posture; no } \\
\text { fidgeting. }\end{array}$ \\
\hline
\end{tabular}

10 In this coding rubric, sequencing is used to mean the arrangement of thoughts, information and actions in an effective order. 
Appendix II - Tracking of Sub-factors of Mayors' Motivation Summedup in Table 3

\begin{tabular}{|l|c|c|c|c|c|c|}
\cline { 2 - 7 } \multicolumn{1}{c|}{} & V1 & V2 & V3 & C4 & C5 & C6 \\
\hline Security & $\mathbf{4}$ & $\mathbf{3}$ & $\mathbf{6}$ & $\mathbf{7}$ & $\mathbf{5}$ & $\mathbf{6}$ \\
\hline Security of office & 2 & 1 & 2 & 3 & 2 & 4 \\
\hline Financial security & 1 & 1 & 1 & 1 & 1 & 1 \\
\hline Security of future political career & 1 & 1 & 3 & 3 & 2 & 1 \\
\hline Recognition & $\mathbf{3}$ & $\mathbf{5}$ & $\mathbf{7}$ & $\mathbf{2}$ & $\mathbf{8}$ & $\mathbf{4}$ \\
\hline Prestige of holding office & 2 & 3 & 2 & 1 & 2 & 2 \\
\hline Reputation as recognized leader & 1 & 1 & 1 & 1 & 4 & 1 \\
\hline Party recognition and reward & - & 1 & 4 & - & 2 & 1 \\
\hline Dedication & $\mathbf{8}$ & $\mathbf{9}$ & $\mathbf{9}$ & $\mathbf{6}$ & $\mathbf{9}$ & $\mathbf{7}$ \\
\hline To contribute to community & 4 & 5 & 5 & 2 & 4 & 3 \\
\hline To influence local governance & 1 & 1 & 1 & 1 & 2 & 1 \\
\hline To improve public satisfaction & 3 & 3 & 3 & 3 & 3 & 3 \\
\hline Self-Actualization & $\mathbf{9}$ & $\mathbf{9}$ & $\mathbf{3}$ & $\mathbf{5}$ & $\mathbf{3}$ & $\mathbf{2}$ \\
\hline To be able to influence higher politics & 1 & 1 & 1 & 1 & 1 & 1 \\
\hline To demonstrate personal acumen & 4 & 4 & 1 & 3 & 1 & 1 \\
\hline Dissatisfaction with earlier leadership & 4 & 4 & 1 & 1 & 1 & - \\
\hline Personal satisfaction & $\mathbf{9}$ & $\mathbf{1 0}$ & $\mathbf{1 0}$ & $\mathbf{8}$ & $\mathbf{8}$ & $\mathbf{8}$ \\
\hline Satisfaction with the job & 4 & 5 & 5 & 3 & 3 & 3 \\
\hline Satisfaction from accomplishments & 5 & 5 & 5 & 5 & 5 & 5 \\
\hline Public satisfaction & $\mathbf{4}$ & $\mathbf{4 . 5}$ & $\mathbf{4}$ & $\mathbf{4 . 5}$ & $\mathbf{4 . 5}$ & $\mathbf{4 . 5}$ \\
\hline Motivation to run for re-election & $\mathbf{4}$ & $\mathbf{4}$ & $\mathbf{4}$ & $\mathbf{4}$ & $\mathbf{4}$ & $\mathbf{3}$ \\
\hline
\end{tabular}




\section{Appendix III - In-Depth Interview Questions}

Below are the questions used in interviewing the mayors of each of the six cases studied. In cases where full answers were not obtained from an interviewee, the interviewer followed up with probing questions making every effort to secure answers that fully covered the questions.

Personal characteristics

Gender: $\quad \square$ Male $\quad \square$ Female

Education $\square$ Bachelor $\square$ Master $\quad \square \mathrm{PhD}$

Age group: $\square 30$ or below $\square 31-45 \quad \square$ 46-60 $\square 61$ and above

Term

in office: $\quad \square$ First $\quad \square$ Second $\quad \square$ Third $\quad \square$ More than three terms

Weekly

income: $\quad \square$ 15-25,000 $\square$ 26-37,000 $\square$ 38-100,000 $\square$ 101,000 and above

Partisanship: $\square$ Republican $\square$ Prosperous $\square$ Congress $\square$ Other

Specialization:

Questions related to public service

1. In your opinion, is there a difference between working in the private sector (including owning a business yourself) vs. working in the public sector? Please elaborate on your response.

2. Irrelevant of your work, how do you view public service? How is the mayor's job compared to other public-service jobs? How would you comment on the workload?

3. What does it take to be a successful mayor? What does it take to have/earn the support of the community that you serve?

Questions related to motivation:

4. Looking back, would you recall events, factors or special circumstances that motivated you to run for the mayor's position?

5. What would you say is the main challenge of holding this office (please be specific)? What were the main issues you were determined to solve when campaigning? Why did you consider those issues important for your community?

6. Have those factors remained the same? In other words, is the level of your motivation the same, more or less?

7. On a scale of 1 (least desire) to 5 (highest desire), would you run again and why? 
8. Are there issues that continue to challenge you in your position? Are you pleased with your job performance so far?

9. What, in your opinion, are the major barriers to doing more than what you have accomplished?

\section{Questions related to community priorities}

10. To what extent were you able to resolve community problems/issues/needs?

11.In what direction do you see yourself going forward in your current position?

12. Is there any other government position that you would like to hold in the future?

\section{Appendix IV - Focus Group Questions}

1. In your opinion, are there differences between working in the private sector (including owning a business) and working in the public sector? What type of person would be attracted to public office?

2. From an outsider's viewpoint, how is the mayor's job compared to other publicservice jobs? How would you comment on the mayor's workload?

3. What does it take to be a successful mayor? What does it take to have/earn the support of the community that the mayor is expected to serve?

4. What would you say is the main challenge of holding the mayor's office in this community? What were the main issues the mayor is expected to solve?

5. Are there issues that continue to challenge the community? Are you pleased with the mayor's job performance so far?

6. What, in your opinion, are the major barriers to doing more than what the mayor has accomplished?

7. To what extent did you think the incumbent is capable of resolving the remaining community problems/issues/needs?

8. In what direction do you see him/her going forward in his/her political career? 


\section{Appendix V - Survey Questions}

\section{Personal characteristics}

Gender: $\quad \square$ Male $\quad \square$ Female

Education $\quad \square$ Bachelor $\quad \square$ Master $\quad \square \mathrm{PhD}$

Age group: $\square 30$ or below $\square 31-45 \quad \square 46-60 \quad \square 61$ and above

Occupation: $\square$ Farmer $\square$ Small retailer $\square$ Civil servant $\square$ Shop owner $\square$ Other (please specify)

Weekly

income: $\square 15-25,000 \quad \square 26-37,000 \quad \square 38-100,000 \quad \square 101,000$ and $\square 15-25,000 \square 26-37,000$
above

Partisanship: $\square$ Republican $\quad \square$ Prosperous $\quad \square$ Congress $\quad \square$ Other

Mayor's motivation

1. In your opinion, what drove the incumbent mayor to run for office?

$\square$ To achieve specific goals for the community

$\square$ To achieve personal objective related to career

$\square$ Own prestige

$\square$ Self-actualization

$\square$ Salary and other financial perks

$\square$ Other (please specify):

2. How important is it that a "local" person is in the mayor's position?

$\checkmark$ Extremely important and essential

$\square$ Very important and essential

$\square$ Somewhat important and essential

$\square$ Important but not essential

$\square$ Not important at all

3. Do you think higher salaries would attract better candidates to run for office?

$\square$ Definitely might

$\square$ Perhaps

$\square$ May be irrelevant

$\square$ Not at all 
4. Are you satisfied with the performance of the incumbent mayor?

$\square$ Totally satisfied

$\square$ Satisfied

$\square$ Neither satisfied nor dissatisfied

$\square$ Dissatisfied

$\square$ Totally dissatisfied

5. Would you wish that more qualified/better trained candidates ran for the mayor's position?

$\square$ Yes $\square$ No $\square$ Indifferent

6. How important would you consider a candidate's prior experience (whether in this position or other)?

$\square$ Definitely important

$\square$ Somewhat important

$\square$ Somewhat unimportant

$\square$ Not at all important

7. If you were to name a single characteristic most important for the mayor's office holder, what would that be?

$\square$ Compassion for community needs

$\square$ Understanding of how to get things done

$\square$ Hardworking

$\square$ Well-connected

$\square$ Party affiliation

$\square$ Other (please specify): 